\title{
THE RISK FACTORS OF HYPERTENSION IN INDONESIA (DATA STUDY OF INDONESIAN FAMILY LIFE SURVEY 5)
}

Faktor Yang Mempengaruhi Kejadian Hipertensi Di Indonesia (Studi Data Indonesian Family Life Survey 5 )

\author{
Dewi Nur Khasanah \\ Universitas Airlangga \\ dewi.nur.khasanah-2017@fkm.unair.ac.id
}

\section{ARTICLE INFO}

Article History:

Received:

July, $1^{\text {st }}, 2021$

Revised:

September, $16^{\text {th }}, 2021$

Accepted:

September, $22^{\text {th }}, 2021$

Published online : March, $1^{\text {st }}, 2022$

\section{ABSTRACT}

Background: Hypertension is a worrying disease, as it often does not cause symptoms. According to WHO, this disease affects $22 \%$ of the world's population, while hypertension has affected $25 \%$ of the population in Southeast Asia. In Indonesia, the prevalence of hypertensive disease increases from year to year. The suspected risk factors for hypertension are gender, age, genetics, smoking obesity, physical activity, and stress. Purpose: analyze factors that affect the prevalence of hypertension in Indonesia based on Indonesian Family Life Survey (IFLS) 5 data. Method: this study uses secondary data from Indonesia Family Life Survey (IFLS) 5 with a type of analytical observational research with cross sectional design. There were 4790 respondents who sampled research from 34,239 population. The analysis used is bivariate and multivariate. Results: bivariate analysis using chi-square test obtained factors related to hypertension incidence is gender $(p=0,000)$, age $(\mathrm{p}=0.000)$, employment status $(\mathrm{p}=0.003)$, physical activity $(\mathrm{p}=0.011)$; and obesity $(\mathrm{p}=0.000)$. While through the test of logistic regression factors that affect hypertension is gender $(\mathrm{p}=0,000)$, age $(\mathrm{p}=0.000)$, physical activity $(\mathrm{p}=0.015)$, and obesity $(\mathrm{p}=0.000)$. Conclusion: factors that affect the incidence of hypertension are gender, age, physical activity, and obesity.

Keywords: risk factors, hypertension, indonesia

\section{ABSTRAK}

Latar Belakang: Hipertensi merupakan penyakit yang menghawatirkan, karena penyakit ini sering tidak menimbulkan gejala. Menurut WHO penyakit ini menyerang $22 \%$ penduduk di seluruh dunia, sedangkan penyakit hipertensi telah menyerang $25 \%$ penduduk wilayah Asia Tenggara. Di Indonesia, prevalensi penyakit hipertensi meningkat dari tahun ke tahun. Adapun yang diduga menjadi faktor risiko hipertensi yaitu jenis kelamin, umur, genetik, obesitas merokok, aktifitas fisik, dan stress. Tujuan: menganalisis faktor yang mempengaruhi kejadian hipertensi di Indonesia berdasarkan data Indonesian Family Life Survey (IFLS) 5. Metode: penelitian ini menggunakan data sekunder dari Indonesia Family Life Survey (IFLS) 5 dengan jenis penelitian observasional analitik dengan desain cross sectional. Terdapat 4790 responden yang menjadi sampel penelitian dari 34.239 populasi. Analisis yang digunakan adalah bivariat dan multivariat. Hasil: analisis bivariat yang menggunakan uji chi-square didapatkan faktor yang berhubungan dengan kejadian hipertensi adalah jenis kelamin $(p=0,000)$; umur $(p=0,000)$; status pekerjaan $(p=0,003)$; aktifitas fisik $(p=0,011)$; dan obesitas $(p=0,000)$. Sedangkan melalui uji regresi logistik faktor yang berpengaruh terhadap hipertensi adalah jenis kelamin $(p=0,000)$, umur $(p=0,000)$, aktifitas fisik $(p=0,015)$, dan obesitas $(p=0,000)$. Kesimpulan: faktor yang berpengaruh terhadap kejadian hipertensi adalah jenis kelamin, umur, aktifitas fisik, dan obesitas. Kata kunci: faktor risiko, hipertensi, indonesia
\end{abstract}




\section{INTRODUCTION}

Hypertension is an increase in systolic and diastolic pulses from normal blood pressure to $140 / 90 \mathrm{mmHg}$ in two estimates with a span of five minutes in a completely fresh / calm state (Kemenkes.RI, 2014). Systolic blood pressure is the main measurement that is the basis for determining the diagnosis of hypertension (Soenarta et al., 2015). Hypertension often does not cause symptoms which is called the silent killer.

As indicated by the World Health Organization (WHO), hypertension is a major problem that affects $22 \%$ of the world's population. In Southeast Asia, hypertension affects $25 \%$ of the total population. WHO estimates that worldwide, 1 in 4 men and 1 in 5 women suffer from hypertension. When compared to the number of patients with hypertension, more men than women.

In Indonesia by 2013, hypertension reached $25.8 \%$ and is the third cause of death (Riskesdas, 2013). Meanwhile, the prevalence of hypertension in Indonesia is increasing and is very worrying, reaching $34.11 \%$ attacking adults over the age of 18 years (Riskesdas, 2018. The estimated number of hypertension cases in Indonesia is 63,309,620 people, while the death rate in Indonesia is due to hypertension is 427,210 people.In 2018 it was found that the population who did not regularly check their blood pressure reached $41 \%$.

Hypertension can be influenced by several factors. The risk factors for hypertension are divided into 2 groups, namely factors that cannot be changed (age, gender, and heredity) and factors that can be changed (overweight, smoking, lack of physical activity, and stress) (Kemenkes RI, 2013). In 2018 hypertension in Indonesia mostly affected the female population at a rate of $36.85 \%$ compared to the male population which reached $28.80 \%$. Furthermore, hypertension increases with age, in 2018 hypertension generally affects the $75+$ age group or the older population with a rate of $69.5 \%$. Judging from the level of education, hypertension attacks the highest in the population who have not/never been promoted to $51.6 \%$. Meanwhile, in terms of occupation, the number of people who do not work has a hypertension rate that reaches $39.73 \%$. Cases such as obesity caused by unbalanced nutrition and lack of activity can increase the risk of hypertension. Moreover, the smoking tendency of the population in Indonesia in 2016 reached $46.16 \%$, of which smoking is one of the causes of hypertension.

Based on research from Anggara and Prayitno (2013), factors related to hypertension are age, school, occupation, BMI, smoking tendency, exercise habits, use of liquor (alcohol), sodium intake, and potassium consumption. This is in accordance with the research of Puspita and Haskas (2014) which stated that the factors that influence the incidence of hypertension are age, smoking, and obesity, but in their research, Sartik dkk (2017) mentioned that education and work have no effect on the incidence of hypertension. According to his research, Putra and Ulfah (2016) stated that gender has an effect on the incidence of hypertension, but in Arum (2019), gender has no effect on hypertension. According to Rahmayani (2019), stress factors affect the incidence of hypertension, while in their research, Putra and Ulfah (2016) stress has no effect on hypertension.

Berdasarkan gambaran di atas, dapat digambarkan bahwa hipertensi memiliki faktor yang mempengaruhinya terutama pada perilaku kesehatan. Maka penelitian ini bertujuan untuk menganalisis faktor yang mempengaruhi kejadian hipertensi di Indonesia berdasarkan data dari Indonesian Family Life Survey (IFLS) 5.

\section{METODE}

This research used observational analytic with research design on cross sectional IFLS survey by using secondary data from Indonesia Family Life Survey (IFLS) cycle 5. This survey was conducted continuously starting from IFLS 1 in 1993 to IFLS 5 in 2015 in 13 of the 27 provinces in Indonesia with representative rate of $83 \%$. These provinces included North Sumatra, West Sumatra, South Sumatra, Lampung, DKI Jakarta, West Java, Central Java, East Java, DI Yogyakarta, Bali, West Nusa Tenggara, South Kalimantan, and South Sulawesi. The sample selection in this survey used the stratified random sampling method.

The population of this study was the entire population of Indonesia, amounting to 34,239 individuals recorded in the data of the Indonesia Family Life Survey (IFLS) 5. While the sample in this study was the Indonesian 
Dewi. The Risk Factors Of Hypertension In Indonesia (Data Study Of Indonesian Family Life Survey 5)

population aged 18 years. The sample size was obtained through the data cleaning process, which was 4,790 residents. The process of collecting data was done by selecting the research variables first. These variables included gender, age, last education, employment status, smoking, physical activity, obesity, and stress. After collecting the data, data cleaning was carried out in accordance with the research variables. Furthermore, the data were analyzed by bivariate and multivariate. Bivariate analysis used ChiSquare test. This test was used to select the variables to be included in the multivariate analysis. While the multivariate analysis used logistic regression to determine the factors that influence the incidence of hypertension.

\section{RESULT}

Based on data from IFLS cycle 5, data obtained as many as 4,790 who are Indonesian residents aged 18 years. The following is the distribution of the frequency of occurrence of hypertension.

Table 1. Distribution of Hypertension.

\begin{tabular}{|l|c|c|}
\hline \multirow{2}{*}{ Hypertension } & \multicolumn{2}{|c|}{ Amount } \\
\cline { 2 - 3 } & $\mathrm{n}$ & $\%$ \\
\hline Hypertension & 441 & 9,2 \\
\hline Not Hypertension & 4.349 & 90,8 \\
\hline Total & 4.790 & 100 \\
\hline
\end{tabular}

Source: Indonesian Family Life Survey Data, 2015

Characteristics of respondents in this study include gender, age, education, employment status, smoking, physical activity, obesity, and stress. The distribution of these characteristics will be shown in table 2 .

Table 2. Distribution of Respondents Characteristics and Research Variables

\begin{tabular}{|l|l|l|}
\hline Characteristic & \multicolumn{1}{|c|}{ n } & \multicolumn{1}{c|}{$\%$} \\
\hline Sex & & \\
\hline Male & 4.625 & 96,6 \\
Female & 165 & 3,4 \\
\hline Age & & \\
\hline$\geq 40$ & 1.836 & 38,4 \\
$<40$ & 2.954 & 61,7 \\
\hline Education & & \\
\hline Low (TK-SMP) & 2.317 & 48,4 \\
High (SMA-Sarjana) & 2.473 & 51,6 \\
\hline Employment Status & & \\
\hline Work & 4.544 & 94,9 \\
Unemployment & 2.46 & 5,1 \\
\hline Smoke & & \\
\hline Yes & 4.671 & 97,5 \\
No & 119 & 2,5 \\
\hline Physical Activity & & \\
\hline Yes & 3.240 & 67,6 \\
No & 1.550 & 32,4 \\
\hline
\end{tabular}




\begin{tabular}{|l|l|l|}
\hline Characteristic & \multicolumn{1}{|c|}{ n } & \multicolumn{1}{c|}{$\%$} \\
\hline Obesity & & \\
\hline Obesity & 223 & 4,7 \\
Not Obesity & 4.567 & 95,3 \\
\hline Stress & & \\
\hline Yes & 280 & 5,8 \\
No & 4510 & 94,2 \\
\hline
\end{tabular}

Source: Indonesian Family Life Survey Data, 2015

Table 2 shows male respondents $(96.6 \%)$ are more than female respondents $(3.4 \%)$, while in the $<40$ age group (51.6\%) more than the 40 age group $(38.4 \%)$. The percentage of respondents with higher education $(51.6 \%)$, while those with low education $(48.4 \%)$. The average respondent has a job with a percentage (94.9\%). Respondents who smoked more $(97.5 \%)$ than did not smoke. Respondents who are obese are $4.7 \%$ less than those who are not obese and respondents who are stressed $(5.8 \%)$ are less than those who are not stressed.

Table 3. Relationship between Risk Factors (Gender, Age, Education, Occupational Status, Smoking, Physical Activity, Obesity, and Stress) and Hypertension.

\begin{tabular}{|c|c|c|c|c|c|c|c|c|c|}
\hline \multirow[t]{3}{*}{ No } & \multirow[t]{3}{*}{ Risk Factor } & \multicolumn{4}{|c|}{ Incidence of Hypertension } & \multirow{2}{*}{\multicolumn{2}{|c|}{ Total }} & \multirow{3}{*}{$\begin{array}{c}p \\
\text { Value }\end{array}$} & \multirow{3}{*}{$\begin{array}{c}\text { OR } \\
(95 \% \mathrm{CI})\end{array}$} \\
\hline & & \multicolumn{2}{|c|}{ Hypertension } & \multicolumn{2}{|c|}{$\begin{array}{c}\text { Not } \\
\text { Hypertension }\end{array}$} & & & & \\
\hline & & $\mathrm{n}$ & $\%$ & $\mathrm{n}$ & $\%$ & $\mathrm{n}$ & $\%$ & & \\
\hline \multirow[t]{2}{*}{1} & $\begin{array}{l}\text { Sex } \\
\quad \text { Male } \\
\text { Female }\end{array}$ & $\begin{array}{c}404 \\
37\end{array}$ & $\begin{array}{c}8,7 \\
22,4\end{array}$ & $\begin{array}{c}4221 \\
128\end{array}$ & $\begin{array}{l}91,3 \\
77,6\end{array}$ & $\begin{array}{c}4625 \\
165\end{array}$ & $\begin{array}{l}100 \\
100\end{array}$ & \multirow[t]{2}{*}{0,000} & \multirow[t]{2}{*}{$\begin{array}{c}0,331 \\
(0,226- \\
0,484)\end{array}$} \\
\hline & Total & 441 & 9,2 & 4349 & 90,8 & 4790 & 100 & & \\
\hline \multirow[t]{2}{*}{2} & $\begin{array}{l}\text { Age } \\
\geq 40 \\
<40\end{array}$ & $\begin{array}{l}273 \\
168\end{array}$ & $\begin{array}{c}14,9 \\
57\end{array}$ & $\begin{array}{l}1563 \\
2786\end{array}$ & $\begin{array}{l}85,1 \\
943\end{array}$ & $\begin{array}{l}1836 \\
2954\end{array}$ & $\begin{array}{l}100 \\
100\end{array}$ & \multirow[t]{2}{*}{0,000} & \multirow[t]{2}{*}{$\begin{array}{c}2,897 \\
(2,367- \\
3,545)\end{array}$} \\
\hline & Total & 441 & 9,2 & 4349 & 90,8 & 4790 & 100 & & \\
\hline \multirow[t]{2}{*}{3} & $\begin{array}{c}\text { Education } \\
\text { Low } \\
\text { High }\end{array}$ & $\begin{array}{l}211 \\
230\end{array}$ & $\begin{array}{l}9,1 \\
9,3\end{array}$ & $\begin{array}{l}2106 \\
2243\end{array}$ & $\begin{array}{l}90,9 \\
90,7\end{array}$ & $\begin{array}{l}2317 \\
2473\end{array}$ & $\begin{array}{l}100 \\
100 \\
\end{array}$ & \multirow[t]{2}{*}{0,817} & \multirow[t]{2}{*}{$\begin{array}{c}0,977 \\
(0,803- \\
1,189)\end{array}$} \\
\hline & Total & 441 & 9,2 & 4349 & 90,8 & 4790 & 100 & & \\
\hline \multirow[t]{2}{*}{4} & $\begin{array}{l}\text { Employment } \\
\text { Status } \\
\text { Work } \\
\text { Unemployed }\end{array}$ & $\begin{array}{c}405 \\
36\end{array}$ & $\begin{array}{c}8,9 \\
14,6\end{array}$ & $\begin{array}{c}4139 \\
210\end{array}$ & $\begin{array}{l}91,1 \\
85,4\end{array}$ & $\begin{array}{c}4544 \\
246\end{array}$ & $\begin{array}{l}100 \\
100\end{array}$ & \multirow[t]{2}{*}{0,003} & \multirow[t]{2}{*}{$\begin{array}{c}0,571 \\
(0,395- \\
0,825)\end{array}$} \\
\hline & Total & 441 & 9,2 & 4349 & 90,8 & 4790 & 100 & & \\
\hline \multirow[t]{2}{*}{5} & $\begin{array}{c}\text { Smoke } \\
\text { Yes } \\
\text { No }\end{array}$ & $\begin{array}{c}427 \\
14\end{array}$ & $\begin{array}{c}9,1 \\
11,8\end{array}$ & $\begin{array}{c}4244 \\
105\end{array}$ & $\begin{array}{l}90,9 \\
88,2\end{array}$ & $\begin{array}{c}4671 \\
119\end{array}$ & $\begin{array}{l}100 \\
100\end{array}$ & \multirow[t]{2}{*}{0,328} & \multirow[t]{2}{*}{$\begin{array}{c}0,755 \\
(0,428- \\
1,330)\end{array}$} \\
\hline & Total & 441 & 9,2 & 4349 & 90,8 & 4790 & 100 & & \\
\hline 6 & $\begin{array}{l}\text { Physical Activity } \\
\text { Yes } \\
\text { No } \\
\text { Total }\end{array}$ & $\begin{array}{l}322 \\
119 \\
441\end{array}$ & $\begin{array}{l}9,9 \\
7,7 \\
9,2\end{array}$ & $\begin{array}{l}2918 \\
1431 \\
4349\end{array}$ & $\begin{array}{l}90,1 \\
92,3 \\
90,8\end{array}$ & $\begin{array}{l}3240 \\
1550 \\
4790\end{array}$ & $\begin{array}{l}100 \\
100 \\
100\end{array}$ & 0,011 & $\begin{array}{c}1,327 \\
(1,065- \\
1,653)\end{array}$ \\
\hline
\end{tabular}




\begin{tabular}{|c|c|c|c|c|c|c|c|c|c|}
\hline \multirow[t]{2}{*}{7} & $\begin{array}{l}\text { Obesity } \\
\text { Obesity } \\
\text { Not Obesity }\end{array}$ & $\begin{array}{c}48 \\
393 \\
\end{array}$ & $\begin{array}{c}21,5 \\
8,6\end{array}$ & $\begin{array}{c}175 \\
4174\end{array}$ & $\begin{array}{l}78,5 \\
91,4\end{array}$ & $\begin{array}{c}223 \\
4567\end{array}$ & $\begin{array}{l}100 \\
100\end{array}$ & \multirow[t]{2}{*}{0,000} & \multirow[t]{2}{*}{$\begin{array}{c}2,913 \\
(2,082- \\
4,075)\end{array}$} \\
\hline & Total & 441 & 9,2 & 4349 & 90,8 & 4790 & 100 & & \\
\hline \multirow[t]{3}{*}{ No } & Risk Factor & \multicolumn{4}{|c|}{ Incidence of Hypertension } & \multirow{2}{*}{\multicolumn{2}{|c|}{ Total }} & \multirow{3}{*}{$\begin{array}{c}p \\
\text { Value }\end{array}$} & \multirow{3}{*}{$\begin{array}{c}\text { OR } \\
(95 \% \mathrm{CI})\end{array}$} \\
\hline & & \multicolumn{2}{|c|}{ Hypertension } & \multicolumn{2}{|c|}{$\begin{array}{c}\text { Not } \\
\text { Hypertension }\end{array}$} & & & & \\
\hline & & $\mathrm{n}$ & $\%$ & $\mathrm{n}$ & $\%$ & $\mathrm{n}$ & $\%$ & & \\
\hline \multirow[t]{2}{*}{8} & $\begin{array}{c}\text { Stress } \\
\text { Yes } \\
\text { No }\end{array}$ & $\begin{array}{c}28 \\
413\end{array}$ & $\begin{array}{l}10 \\
9,2\end{array}$ & $\begin{array}{c}252 \\
4097\end{array}$ & $\begin{array}{c}90 \\
90,8\end{array}$ & $\begin{array}{c}280 \\
4510\end{array}$ & $\begin{array}{l}100 \\
100\end{array}$ & \multirow[t]{2}{*}{0,636} & \multirow[t]{2}{*}{$\begin{array}{c}1,102 \\
(0,736- \\
1,650)\end{array}$} \\
\hline & Total & 441 & 9,2 & 4349 & 90,8 & 4790 & 100 & & \\
\hline
\end{tabular}

Source: Indonesian Family Life Survey Data, 2015

Table 3 shows the results of bivariate analysis using the Chi Square test, where there are 5 variables that have a significant relationship with the incidence of hypertension, namely gender $(\mathrm{p}=0.000 ; \mathrm{OR}=$ $0.331 ; 95 \%$ CI $=0.226-0.484)$; age $(\mathrm{p}=0.000$; $\mathrm{OR}=2.897 ; \quad 95 \% \quad \mathrm{CI}=2.367-3.545)$; employment status $(\mathrm{p}=0.003$; OR $=0.571 ; 95 \%$ $\mathrm{CI}=0.395-0.825)$; physical activity $(\mathrm{p}=0.011$; $\mathrm{OR}=1.327 ; 95 \% \mathrm{CI}=1.065-1.653)$; and obesity $(\mathrm{p}=0.000 ; \mathrm{OR}=2.913 ; 95 \% \mathrm{CI}=2.082-4.075)$. While the variable that does not have a significant relationship with the incidence of hypertension is the education $(p=0,817)$, smoking $(\mathrm{p}=0,328)$, and stress $(\mathrm{p}=0,636)$.

Furthermore, multivariate analysis was carried out, in which the variables included in the multivariate analysis were variables that had significant value in the bivariate analysis using the chi-square test with a $p$ value of less than $0.05(\mathrm{p}<0.25)$. Variables that have a $\mathrm{p}$ value $<0.25$ are gender, age, work status, physical activity, and obesity. The following multivariate analysis using logistic regression test is shown in table 4.

Table 4. Logistic Regression Analysis of Factors Affecting the Incidence of Hypertension

\begin{tabular}{|c|c|c|c|c|c|c|}
\hline \multirow[t]{2}{*}{ Category } & \multirow[t]{2}{*}{ B } & \multirow[t]{2}{*}{ Wald } & \multirow[t]{2}{*}{ Sig } & \multirow[t]{2}{*}{$\operatorname{Exp}(\mathrm{B})$} & \multicolumn{2}{|c|}{ 95\%C.I for $\operatorname{EXP}(B)$} \\
\hline & & & & & Lower & Upper \\
\hline Sex & & & & & & \\
\hline $\begin{array}{l}\text { Male } \\
\text { Female (reference) }\end{array}$ & 0,826 & 16,939 & 0,000 & 2,284 & 1,541 & 3,386 \\
\hline Age & & & & & & \\
\hline $\begin{array}{l}\geq 40 \\
<40 \text { (reference) }\end{array}$ & $-1,021$ & 96,373 & 0,000 & 0,360 & 0,294 & 0,442 \\
\hline $\begin{array}{l}\text { Physical Activity } \\
\text { Yes } \\
\text { No (reference) }\end{array}$ & $-0,274$ & 5,767 & 0,016 & 0,760 & 0,608 & 0,951 \\
\hline $\begin{array}{l}\text { Obesity } \\
\text { Obesity } \\
\text { Not Obesity } \\
\text { (reference) } \\
\text { Constant }\end{array}$ & $\begin{array}{l}-0,962 \\
2,263\end{array}$ & $\begin{array}{r}29,561 \\
101,813\end{array}$ & $\begin{array}{l}0,000 \\
0,000\end{array}$ & $\begin{array}{l}0,382 \\
9,612\end{array}$ & 0,270 & 0,541 \\
\hline
\end{tabular}

Source: Indonesian Family Life Survey Data, 2015

The results of the multivariate analysis in table 4 show that the variables were analyzed together using logistic regression test which resulted in 4 variables that had significant values on the incidence of hypertension. The variables are gender, age, physical activity, and obesity.

\section{DISCUSSION}

\section{The Effect of Gender with Hypertension}

Based on the results of the cross tabulation in table 3, there were 4790 respondents who were tested, from 4625 $(96.6 \%)$ male respondents there were 404 (8.7\%) people who suffered from hypertension 
and $4221(91.3 \%)$ who did not. hypertension. Meanwhile, from 165 (3.4\%) female respondents, 37 (22.4\%) suffered from hypertension and $128(77.6 \%)$ did not.

Based on the results of the bivariate analysis using the Chi Square test, the value ( $\mathrm{p}$ $=0.000 ; \mathrm{OR}=0.331)$, the $\mathrm{p}$ value shows less than (0.05), which means that there is a relationship between gender and the incidence of hypertension, while in the multivariate analysis which uses logistic regression produces a value $(\mathrm{p}=0.000 ; \mathrm{OR}=2,284)$, the $\mathrm{p}$ value shows less than $(0.05)$ which means that the gender variable has an effect on the incidence of hypertension. The risk of the influence of sex on hypertension is indicated by the Odd Ratio (OR) value of 2.284 , which means that male respondents have a 2.284 times greater risk of experiencing hypertension than female respondents.

The results of this study are in accordance with the results of research conducted by Wahyuni and Eksanoto (2013) which stated that there is a relationship between gender and the incidence of hypertension with $\mathrm{p}$ value $=0.000$. In addition, the research conducted by Arifin dkk, (2016) was also in accordance with this recent study, which proved that there is a significant relationship between gender and the incidence of hypertension with a value $(\mathrm{p}=0.015 ; \mathrm{OR}=$ $0.980)$.

Sometimes a man can experience indications of hypertension in his late thirties, while women often experience hypertension during menopause. The spread of hypertension in men is almost the same as in women, but women who have not experienced menopause will be protected by the hormone estrogen which plays a role in increasing levels of High Density Lipoprotein (HDL). However, for women who have entered menopause or old age, the level of the hormone estrogen in women will decrease, so that women become susceptible to hypertension. Meanwhile, cases of hypertension in men are often associated with high activity which causes other factors to appear, such as fatigue, smoking behavior, or unhealthy eating patterns (Amanda and Martini, 2018)

It can be concluded that the gender variable has a significant effect on the incidence of hypertension. It can be seen that female respondents suffer from hypertension more than men, because women are more susceptible to hypertension, especially in old age.

\section{The Effect of Age with Hypertension.}

Based on the results of the cross tabulation in table 3, there were 4790 respondents who were tested, from 1836 (38.3\%) respondents aged 40 there were 273 $(14.9 \%)$ people who suffered from hypertension and $1563(85.1 \%)$ who did not. . Meanwhile, of the 2954 (61.7\%) respondents aged <40, $168(5.7 \%)$ had hypertension and $2786(90.8 \%)$ did not.

It can be seen from the results of the bivariate analysis using the Chi Square test, the value $(\mathrm{p}=0.000 ; \mathrm{OR}=2.897)$, the $\mathrm{p}$ value shows less than (0.05), which means that the age variable has a relationship with the incidence of hypertension, while in the multivariate analysis the using logistic regression resulted in a value $(\mathrm{p}=0.000 ; \mathrm{OR}=$ $0.360)$, the $p$ value showed less than $(0.05)$, which means that the age variable has an effect on the incidence of hypertension. The risk of the age of the respondent with hypertension is shown in the Odd Ratio (OR) value of 0.360 , which means that respondents aged 40 have 0.360 times more serious risk of developing hypertension compared to respondents aged $<40$.

The results of this study are in accordance with research conducted by Puspita and Haskas (2014) which stated that there was a relationship between age and the incidence of hypertension with a value ( $p=$ 0.009 ; OR = 3.6). Meanwhile, the research conducted by Sartik dkk (2017) proved that there was an influence between age and the incidence of hypertension with a value $(\mathrm{p}=$ $0.000 ; \mathrm{OR}=6,138$ ).

The proportion of hypertension increases with age (Kemenkes RI, 2019). Physiologically, the higher a person's age, the higher the risk of developing hypertension. At the age between 30-65 years, systolic pressure increases normally by $20 \mathrm{mmHg}$ and continues to increase after the age of 70 years. As the person ages, blood vessel pressure in a person's body will increase, and there are degenerative diseases that often occur in old age. 
it can be concluded that there is an influence between age and the incidence of hypertension. This is because respondents who are older are more likely to suffer from hypertension since 40 years and over. It can be seen that the older a person is, the more susceptible he is to hypertension, because when a person is old, organ function will decrease and he is more sensitive to any disease, including hypertension. In contrast to someone who is still young, he has a strong immune system and good organ function that can prevent all diseases from entering the body. However, someone who is still young can get hypertension. This is evidenced in the Indonesian population aged over 20 years who already have risk factors for hypertension (Azhari, 2017).

\section{The Effect of Employment Status with Hypertension}

Based on the results of the cross tabulation in table 3, there were 4790 respondents who were tested, from 4544 respondents who had jobs there were 405 (8.9\%) people who suffered from hypertension and 4139 (91.1\%) who did not have hypertension, while from 246 respondents who did not have a job there are $36(14.6 \%)$ who suffer from hypertension and 210 (85.4\%) people who do not have hypertension.

Based on the results of the bivariate analysis using the Chi Square test in table 3, it shows the $p$ value $=0.003$ where the $p$ value $<\alpha(0.05)$ which means there is a relationship between employment status and the incidence of hypertension. The results of the analysis also obtained an Odd Ratio (OR) value of 0.571 , which means that respondents who have jobs have a risk of 0.571 times greater than respondents who do not have jobs. It is known that the value of $\mathrm{OR}<1$, then respondents who do not have a job have a risk of 1.75 times greater than respondents who have a job. However, in a multivariate analysis, employment status had no effect on the incidence of hypertension.

The results of this analysis are in line with research by Anggara and Prayitno (2013) which showed that there is a significant relationship between employment status and the incidence of hypertension with a value $(\mathrm{p}=$ 0.000 ; OR $=8.95$ ). In addition, the results of research conducted by Azhari (2017) were also in line with the results of the analysis of this study which stated that there is a significant relationship between work status and the incidence of hypertension with a value ( $\mathrm{p}=$ $0.006 ; \mathrm{OR}=3.208$ ) .

In general, People do some physical activities that expend energy during work. When compared with people who do not work, it is much different since they do not have any activity that makes the body to be active. Lack of physical activity is one of the factors of hypertension. This is in line with research by Arda, Ali, and Mustapa (2018) which stated that someone who does not work has a 2.71 times greater risk of suffering from hypertension than someone who works.

it can be concluded that there is a relationship between work status and the incidence of hypertension. It can be seen in the results of the research that respondents who do not work suffer from hypertension more than those who work. This is because someone who works has done physical activity which has an effect on hypertension.

\section{The Effect of Physical Activity with Hypertension}

Based on the results of the cross tabulation in table 3, there were 4790 respondents who were tested, from 3240 (67.6\%) respondents who did physical activity there were $322(9.9 \%)$ people who suffered from hypertension and $2918(90.1 \%)$ who did not. . Meanwhile, from 1550 (32.4\%) respondents who did not do physical activity, there were $119(7.7 \%)$ who suffered from hypertension and 1413 (92.3\%) people who did not.

Based on the results of the bivariate analysis using the Chi Square test, the value $(\mathrm{p}=0.011$; $\mathrm{OR}=1.327)$, the $\mathrm{p}$ value showed $\mathrm{p}<\alpha(0.05)$, which means that there is a relationship between physical activity and the incidence of hypertension, while in the multivariate analysis which using logistic regression produces a value $(\mathrm{p}=0.016$; $\mathrm{OR}=0.730)$, the $\mathrm{p}$ value shows $\mathrm{p}<\alpha(0.05)$, which means that physical activity affects the incidence of hypertension. The risk factors for physical activity with hypertension were shown by the results of multivariate analysis which resulted in an OR value of 0.751 . It is known that the value of OR $<1$, then respondents who do not do physical activity have a risk of 1.33 times greater. 
The results of this study are in accordance with the research of Nelli Safitri, dan Suyanto (2016) which showed that there was a significant relationship between physical activity and the incidence of hypertension with a value $(\mathrm{p}=0.000 ; \mathrm{OR}=14,479)$. In addition, the results of research conducted by (Arifin $\mathrm{dkk}, 2016)$ were also in line with the results of the analysis of this study which states that there is a relationship between physical activity and the incidence of hypertension with a value $(\mathrm{p}=0.017 ; \mathrm{OR}=1.424)$.

People who are less mobile will tend to have a higher heart rate so the heart muscle will work harder with each contraction. The harder the heart muscle works in ensuring blood, the greater the blood pressure imposed on the arteries (Harahap et al., 2017). Therefore, physical activity greatly affects the stability of blood pressure. Physical activity can increase the risk of being overweight, because when the body does not move it will cause a lack of fat which results in the body being overweight.

It can be concluded that there is an influence between physical activity and the incidence of hypertension. However, the number of respondents who do not do physical activity is smaller, this is evidenced by the number of respondents who do physical activity suffer from hypertension more than those who do not do physical activity. So it is possible that people who have been doing physical activity do not suffer from hypertension, because it can attack any condition related to the factors that cause hypertension.

\section{The Effect of Obesity with Hypertension}

Based on the results of the cross tabulation in table 3, there were 4790 respondents who were tested, from 223 (4.7\%) respondents who were obese, there were 48 $(21.5 \%)$ people who suffered from hypertension and $175(78.5 \%)$ who did not. Meanwhile, of the 4567 (95.3\%) respondents who were not obese, there were $393(8.6 \%)$ who had hypertension and 4174 (91.4\%) who did not.

Based on the results of the bivariate analysis using the Chi Square test, the value ( $\mathrm{p}$ $=0.000 ;$ OR $=1.102)$, the $\mathrm{p}$ value showed $\mathrm{p}$ less than (0.05), which means that there is a relationship between obesity and the incidence of hypertension, while in the multivariate analysis which using logistic regression produces a value $(\mathrm{p}=0.000 ; \mathrm{OR}=0.382)$, the $\mathrm{p}$ value showed $\mathrm{p}$ less than (0.05), which means obesity has an effect on the incidence of hypertension. The risk factors for obesity with hypertension are shown by the results of multivariate analysis which produces an OR value of 0.382 , which means that respondents who are obese are 0.382 times more at risk of developing hypertension than respondents who are not obese.

The results of this analysis are in line with research by Agustina and Raharjo (2015) which stated that there is a relationship between obesity and the incidence of hypertension with a value $(\mathrm{p}=0.038$; OR $=$ 3.5). In addition, the results of research conducted by Rahmayani (2019) were also in line with the results of the analysis of this study which stated that there is a relationship between obesity and the incidence of hypertension with a value $(\mathrm{p}=0.007$; OR $=$ 5.573).

Obesity is one of the risk factors for hypertension. When a person is overweight, that person will need a lot of blood to supply oxygen and food to the body's tissues. This causes the volume of blood to increase, which puts greater pressure on the artery walls. So in the study of (Puspita, 2014), it stated that the risk of people with obese was 8.4 times greater for hypertension than people who were not obese.

It can be concluded that there is an influence between obesity and the incidence of hypertension. From the results of the analysis, it is known that respondents who are obese have a small risk, this is because the number of respondents who are not obese suffers from hypertension even though the results of the analysis show a significant value. However, obesity has a significant effect on blood pressure, because in general, obese people will find it difficult to move and when they want to move they will need strong energy which causes blood pressure to continue to rise.

\section{CONCLUCION}

Based on the results of research analysis on risk factors for hypertension in Indonesia, it can be concluded that through the logistic regression test the factors that influence hypertension are gender, age, physical activity, and obesity. 
Dewi. The Risk Factors Of Hypertension In Indonesia (Data Study Of Indonesian Family Life Survey 5)

\section{SUGESSTION}

Patients with hypertension in Indonesia are more common in men than women. So it is expected that men pay more attention to their health by checking blood pressure regularly so that they can detect hypertension early. Patients with hypertension are more common at the age of 40 than age of $<40$. So it is expected to apply a healthy and clean lifestyle to avoid hypertension.

Patients with hypertension who do physical activity have a greater risk. So it is expected to continue to do physical activities such as exercise and take hypertension medication regularly. Hypertension often occur in the group of respondents who are not obese, so it is hoped that they will be more aware of other causal factors that may be the cause of hypertension. Hopefully, this research can be used as an evaluation and comparison material for further research in more detail.

\section{REFFERENCES}

Agustina, R. and Raharjo, B. B. (2015) 'Faktor Risiko Yang Berhubungan Dengan Kejadian Hipertensi Usia Produktif (2554 Tahun)', Unnes Journal of Public Health, 4(4), pp. 146-158. doi: 10.15294/ujph.v4i4.9690.

Amanda, D. and Martini, S. (2018) 'Hubungan Karakteristik dan Obesitas Sentral dengan Kejadian Hipertensi', Jurnal Berkala Epidemiologi, 6(1), p. 43. doi: 10.20473/jbe.v6i12018.43-50.

Anggara, F. H. D. and Prayitno, N. (2013) 'Faktor-Faktor Yang Berhubungan Dengan Tekanan Darah Di Puskesmas Telaga Murni, Cikarang Barat Tahun 2012', Jurnal Ilmiah Kesehatan, 5(1). doi: 10.1002/9781444324808.ch36.

Arda, Z. A., Ali, R. and Mustapa, M. (2018) 'Hipertensi dan Faktor Risikonya di Puskesmas Motolohu Kabupaten Pohuwato', Gorontalo Journal of Public Health, 1(1), p. 032. doi: 10.32662/gjph.v1i1.148.

Arifin, M. H. B. M., Weta, I. W. and Ratnawati, N. L. K. A. (2016) 'FaktorFaktor Yang Berhubungan Dengan Kejadian Hipertensi Pada Kelompok Lanjut Usia Di Wilayah Kerja Upt Puskesmas Petang I Kabupaten Badung Tahun 2016', E-Jurnal Medika Udayana, 5(7).
JPH RECODE March 2022; 5 (2): 80-89 http://e-journal.unair.ac.id/JPHRECODE http://dx.doi.org/10.20473/jphrecode.v5i2.27923

Arum, Y. T. G. (2019) 'Hipertensi pada Penduduk Usia Produktif (15-64 Tahun)', Higeia Journal of Public Health Research and Development, 3(3), pp. 625-634.

Azhari, M. H. (2017) 'Faktor-Faktor yang Berhubungan dengan Kejadian Hipertensi di Puskesmas Makrayu Kecamatan Ilir Barat II Palembang', Jurnal Aisyah: Jurnal Ilmu Kesehatan, 2(1), pp. 23-30. doi: 10.30604/jika.v2i1.29.

Harahap, R. A. et al. (2017) 'Pengaruh Aktivitas Fisik Terhadap Kejadian Hipertensi Pada Laki-Laki Dewasa Awal (18-40 Tahun) Di Wilayah Puskesmas Bromo Medan Tahun 2017', Jurnal Muara Sains, Teknologi, Kedokteran dan Ilmu Kesehatan, 1(2), pp. 68-73. doi: 10.24912/jmstkik.v1i2.951.

Kemenkes.RI (2014) 'Pusdatin Hipertensi', Infodatin, (Hipertensi), pp. 1-7. doi: 10.1177/109019817400200403.

Kemenkes RI (2013) 'Pedoman Teknis Penemuan dan Tatalaksana Hipertensi'.

Kemenkes RI (2019) 'Hipertensi Si Pembunuh Senyap', Kementrian Kesehatan RI, pp. 1-5. Available at: https://pusdatin.kemkes.go.id/resources/ download/pusdatin/infodatin/infodatinhipertensi-si-pembunuh-senyap.pdf.

Nelli Safitri, Suyanto, W. R. B.-B. (2016) 'Analisis Faktor Risiko Kejadian Hipertensi Pada Masyarakat Di Pesisir Sungai Siak Kecamatan Rumbai Kota Pekan Baru', Jom Fk, 3(1), pp. 1-15.

Puspita, E. and Haskas, Y. (2014) 'Faktor Risiko Kejadian Hipertensi Pada Pasien Yang Berobat Di Poliklinik Rumah Sakit Umum Daerah Labuang Baji Makassar', Jurnal Ilmiah Kesehatan Diagnosis: STIKES Nani Hasanuddin Makassar, 5, pp. 58-64. Available at: 
http://ejournal.stikesnh.ac.id/index.php/j ikd/article/view/725/603.

Putra, A. M. P. and Ulfah, A. (2016) 'Analisis Faktor Risiko hipertensi di Puskesmas Kelayan Timur Kota Banjarmasin', Jurnal Ilmiah Ibnu Sina, 1(2), pp. 256264.

Rahmayani, S. T. (2019) 'FAKTOR-FAKTOR RISIKO KEJADIAN HIPERTENSI PRIMER PADA USIA 20-55 TAHUN DI POLIKLINIK PENYAKIT DALAM RSUD 45 KUNINGAN', Universitas Islam Al-Ihya Kuningan, 1(4).

Riskesdas (2013) RISET KESEHATAN DASAR 2013, Kementrian Kesehatan RI. doi: 10.1126/science.127.3309.1275.

Riskesdas (2018) 'Hasil Utama Riset Kesehata Dasar (RISKESDAS)', Kementrian Kesehatan RI. doi: 10.1088/17518113/44/8/085201.

Sartik, S., Tjekyan, R. S. and Zulkarnain, M. (2017) 'Faktor-Faktor Risiko Dan Angka Kejadian Hipertensi Pada Penduduk Palembang', Jurnal Ilmu Kesehatan Masyarakat, 8(3), pp. 180191. doi: $10.26553 / \mathrm{jikm} .2017 .8 .3 .180-$ 191.

Soenarta, A. A. et al. (2015) PEDOMAN TATALAKSANA HIPERTENSI PADA PENYAKIT KARDIOVASKULAR. doi: 10.1103/PhysRevD.42.2413.

Wahyuni and Eksanoto, D. (2013) 'Hubungan Tingkat Pendidikan dan Jenis Kelamin dengan Kejadian Hipertensi di Kelurahan Jagalan di Wilayah Kerja Puskesmas Pucangsawit Surakarta', Jurnal Ilmu Keperawatan Indonesia, 1(1). 